\title{
Immunological studies of the placenta in systemic lupus erythematosus
}

\author{
D. M. GRENNAN, J. N. McCORMICK, DAVINA WOJTACHA, M. CARTY, \\ AND W. BEHAN
}

From the Centre for Rheumatic Diseases and University Department of Medicine, Royal Infirmary, Glasgow; Queen Mother's Maternity Hospital, Glasgow; and Rheumatic Diseases Unit, Northern General Hospital, Edinburgh

SUMMARY An immunological study was made of the placentae from 5 mothers with lupus erythematosus. 3 of the 5 mothers had anti-DNA antibodies in their sera at the time of delivery and in one of these anti-DNA antibodies were detected in the cord blood. This patient had active renal disease and serological evidence suggestive of circulating immune complexes in her blood at the time of delivery. Immunofluorescence studies showed granular deposition of immunoglobulin and C3 on the trophoblast basement membrane similar to that previously described on the glomerular basement membrane in systemic lupus erythematosus. Anti-DNA antibodies were eluted from the placenta in this case. We suggest that immune complex deposition on the trophoblast basement membrane in patients with active systemic lupus erythematosus may play a part in the increased fetal mortality in this disease.

There is much indirect evidence that circulating immune complexes mediate tissue damage in systemic lupus erythematosus (SLE). The evidence includes the demonstration of circulating DNA and antibodies to native and denatured DNA in the sera of patients with SLE (Tan et al., 1966; Schur and Sandson, 1968) while serum complement levels generally fall during periods of disease activity (Schur and Sandson, 1968). Immunoglobulin deposition has been shown in the renal glomerulus (Paronetto and Koffler, 1965; Koffler et al., 1967; Agnello et al., 1973), in the dermoepidermal junction area of the skin (Tan and Kunkel, 1966) and in the splenic vasculature (Grishman and Churg, 1971).

In pregnant mothers with SLE the placenta might be another potential site for immune complex deposition. The demonstration of immune complexes in the placenta would be of particular interest in view of the increased fetal mortality in SLE (Mund et al., 1963; Fraga et al., 1974). The immunological characteristics of placentae from healthy mothers have been previously noted (McCormick et al., 1971;

Accepted for publication August 10, 1977

Correspondence to Dr J. N. McCormick, Rheumatic Diseases Unit, Northern General Hospital, Ferry Road, Edinburgh EH5 2DQ
Faulk et al., 1974), and in this study we have looked at the immunohistology of placentae from 5 mothers with SLE at varying stages of disease activity. The antibody activity of immunoglobulin eluted from the placentae has also been examined.

\section{Patients}

\section{PATIENT A}

Aged 30 years. At the onset of her second pregnancy she had a 15-year history of SLE manifesting with malar rash, photosensitivity, Raynaud's phenomenon, mild joint pains, and, during disease exacerbations, with thrombocytopenia and leucopenia. There had been no clinical or biochemical evidence of renal disease and she had been treated with low doses of prednisolone. During her first pregnancy, 7 years previously, she had been relatively well throughout while taking $5 \mathrm{mg}$ prednisolone daily but exacerbation of joint disease developed after delivery. Throughout this second pregnancy she took $5 \mathrm{mg}$ prednisolone daily and was well apart from discoid lesions on the face and arms and Raynaud's phenomenon. DNA binding capacity varied from $39 \%$ to $42 \%$ during the pregnancy but 3 months after delivery rose to $88 \%$ with no worsening of clinical disease activity. 


\section{PATIENT B}

A Chinese woman, aged 28 years at the onset of her first pregnancy. She had a 3-year history of SLE which had started with mild polyarthritis, erythematous rash on malar areas and limbs, and proteinuria. She had been treated with corticosteriods but at the beginning of the pregnancy was on no therapy, was clinically asymptomatic, and antinuclear factor was negative. At 29 weeks pain and swelling developed in the proximal interphalangeal joints of the hands. 2 weeks later she felt generally unwell and was depressed and anaemic. She had $5 \mathrm{~g}$ proteinuria in a 24-hour urine collection, antinuclear antibodies in the serum at a titre of $1: 256$, and DNA binding capacity at $83 \%$. Labour was induced at 36 weeks because of hypertension and in the post-partum period she improved on treatment with prednisolone.

\section{PATIENT C}

Aged 27 years, with a 12-year history of mild SLE which had started as a nondeforming polyarthritis associated with facial and truncal rashes, and LE cells in more than one blood film. No clinical or biochemical evidence of renal disease. She had had three previous pregnancies, the first ending in spontaneous abortion at 9 weeks, while in the second and third she was well on $10 \mathrm{mg}$ prednisolone daily throughout and had normal full-term deliveries. During this fourth pregnancy and in the postpartum period, she remained well while taking $10 \mathrm{mg}$ prednisolone daily. DNA binding capacity varied between $45 \%$ and $60 \%$ throughout the pregnancy and in the post-partum period.

\section{PATIENT D}

Aged 30 years, she had developed polyarthritis, fever, alopecia, and mouth ulceration 4 years previously, 2 months after her second pregnancy. She was treated with corticosteroids and symptomatically improved. During this third pregnancy she remained well and was taking $7.5 \mathrm{mg}$ prednisolone daily. Antinuclear antibodies were present in her serum during pregnancy at a titre of $1: 64$, while DNA binding capacity was borderline at $32 \%$.

\section{PATIENT E}

Aged 35 years, she had had discoid lupus lesions intermittently for 15 years which had been treated with topical corticosteroids, and during this only pregnancy she was well apart from a patch of alopecia on her scalp. Antinuclear antibodies were present in her serum at a titre of $1: 1000$ throughout the pregnancy, but DNA binding capacity remained within normal limits $(<30 \%)$.
In summary, the first patient had active, nonrena SLE with anti-DNA antibodies, the second hogd active renal SLE with anti-DNA antibodies, the third had clinically inactive SLE with anti-DNA antibodies, the fourth had inactive SLE with an位nuclear antibodies, and the last had inactive discofd lupus.

\section{Methods}

COLLECTION OF SERA AND PLACENTAL TISSUE Serum was stored from maternal and umbilical corft blood collected immediately after delivery. The serim was tested for antinuclear factor, rheumatoid factor, DNA binding capacity, and C3 and C4 complement components. Within one hour of delivery the placenta was perfused via a superficial vein with cold phosphate-buffered saline (PBS) at $\mathrm{pH} 7.4$ affd blocks of tissue measuring approximately $0.5 \times 100$ $\mathrm{cm}$ cut from the perfused segments. These blocks were snap-frozen in a dry ice/acetone mixture aitrd stored at $-20^{\circ} \mathrm{C}$ in sealed tubes pending the immunofluorescence studies. The remainder of the placenta was cut in slices, washed in cold PBS, and stored at $-20^{\circ} \mathrm{C}$ for elution studies.

\section{IMMUNOHISTOLOGY}

The globulin fractions of antisera to human Ig区্ C3, and fibrinogen supplied by Eivai Bios Labogtories Ltd, were conjugated with fluorescein isthiocyanate by the dialysis technique of Clark a $\overrightarrow{\mathrm{gd}}$ Shepard (1963). Labelled IgG fractions with the optimum fluorescein/protein ratio $(0.07-0.17)$ we prepared from the conjugates by DEAE-cellulise chromatography (McDevitt et al., 1963). Normal rabbit serum $20 \% \mathrm{v} / \mathrm{v}$ was added to each labelled IgG fraction before use to improve stability and reduce nonspecific binding of conjugated IgG. Staining reactions and tests of immunofluorescerse specificity were performed as previously described in studies of normal placentae (McCormick et ä., 1971). Some sections of placenta from patient $B$ wegre incubated for 30 minutes with deoxyribonuclease (Sigma) in PBS at a concentration of $0.28 \mathrm{mg} / \mathrm{s}$ ) (equivalent to $4 \mathrm{Kunitz} \mathrm{U} / \mathrm{ml}$ ) before staining with the labelled antisera while control sections w\&e washed in PBS alone. The stained sections wepe examined with a Leitz Ortholux fluorescence miorscope equipped with a Ploem incident illuminar and FITC interference filter.

\section{ELUTION STUDIES}

The bulk of the placental tissue was homogenisfod with a Silverson mixer and washed repeatedly stirring with chilled PBS until the washings were free of protein as judged by the optical densify 
measured at $280 \mathrm{~nm}$. Each washed homogenate was stirred for 2 hours at $4^{\circ} \mathrm{C}$ with isotonic saline in $0.05 \mathrm{M}$ glycine $/ \mathrm{HCl}$ buffer $(\mathrm{pH} 2.5)$, was then centrifuged, and the supernate stored at $4^{\circ} \mathrm{C}$. Washing of the homogenate at $\mathrm{pH} 2.5$ was repeated twice more, the three supernates were pooled, the $\mathrm{pH}$ adjusted to neutrality by the addition of a small quantity of solid Tris-aminomethane and the pool concentrated by ultrafiltration in 'Centriflo' membrane filters (Amicon).

In parallel with the elutions at acidic $\mathrm{pH}$, washed placental homogenate from patient $B$ was also incubated with deoxyribonuclease (Sigma) at room temperature at a concentration of $0.28 \mathrm{mg} / \mathrm{ml}$ in PBS (equivalent to $4 \mathrm{Kunitz} \mathrm{U} / \mathrm{ml}$ ). A small peak of protein measurable at $280 \mathrm{~nm}$ was detected in the supernate after the incubation with deoxyribonuclease. The supernate was concentrated by ultrafiltration until the final optical density was $2 \cdot 15$ at $280 \mathrm{~nm}$.

After dialysis against PBS all eluates were analysed by immunoelectrophoresis and tested for antinuclear factor, rheumatoid factor, and DNA binding capacity.

\section{ANTINUCLEAR FACTOR}

This was detected by the indirect immunofluorescence technique using either rat liver sections (Beck, 1961) or alcohol-fixed normal blood films as substrate (Alexander and Duthie, 1958). Fourfold dilutions were used to obtain a titre.

\section{RHEUMATOID FACTOR}

This was measured using the $\mathbf{R} 3$ titration kit (Denver Laboratories).

\section{DNA ANTIBODIES}

The Farr technique was used with ${ }^{14} \mathrm{C}$-labelled native $E$. coli DNA as antigen (Hughes, 1971). Results were expressed in terms of DNA binding capacity (normal range for serum $0-30 \%$ ).
C3 AND C4

The $\mathrm{C} 3$ and $\mathrm{C} 4$ complement components were measured by a radial immunodiffusion technique. The normal range for adults is $0.75-1.5 \mathrm{~g} / 1$ for $\mathrm{C} 3$, and $0 \cdot 31-0.45 \mathrm{~g} / 1$ for $\mathrm{C} 4$.

\section{Results}

Table 1 summarises the immunological findings in cord and maternal blood at delivery. In the maternal blood there were antinuclear antibodies in all five specimens. The immunofluorescent pattern was homogeneous in all except the first where a speckled pattern at the higher dilutions and a homogeneous pattern at the lower dilutions were found. The R3 test was negative in all maternal sera except patient $\mathrm{D}$ where a weak positive reaction $(1: 16)$ was found. The DNA binding capacity of maternal serum $E$ was within normal limits, was borderline in serum $D$, while in sera A, B, and C the DNA binding capacity was raised particularly in B where a level of $99 \%$ was found. The C3 level was reduced in maternal serum B only, while $C 4$ levels were slightly reduced in serum from patient $C$ and were very low in serum $B$.

Antinuclear factor titres in cord sera were comparable to those in maternal sera from patient $A$ and $\mathrm{C}$ but not from $\mathrm{D}$ and $\mathrm{E}$. DNA binding capacity was low in all cord sera except that of patient $B$. In this baby the DNA binding capacity had fallen from $96 \%$ to $52 \% 2$ weeks after delivery and to $9 \%$ 8 weeks after delivery.

\section{PLACENTAL IMMUNOFLUORESCENCE}

All placentae appeared macroscopically normal. The results of the immunofluorescent studies on the five placentae are summarised in Table 2. Granular fluorescence was seen with antisera to IgG, C3, and fibrinogen in placental blood vessels and stroma, and homogeneous and granular fluorescence was seen in areas of fibrinoid deposition. Linear and

Table 1 Immunological findings in cord and maternal blood at delivery

\begin{tabular}{|c|c|c|c|c|c|c|c|c|c|c|}
\hline & \multicolumn{2}{|l|}{$\begin{array}{l}\text { Patient } \\
\boldsymbol{A}\end{array}$} & \multicolumn{2}{|l|}{$\boldsymbol{B}$} & \multicolumn{2}{|l|}{$C$} & \multicolumn{2}{|l|}{$D$} & \multicolumn{2}{|l|}{$E$} \\
\hline & Cord & Mother & Cord & Mother & Cord & Mother & Cord & Mother & Cord & Mother \\
\hline $\begin{array}{l}\text { ANF } \\
\text { R3 } \\
\text { DNAB (\%) } \\
\text { C3 (g/1) } \\
\text { C4 (g/l) } \\
\text { Clinical diagnosis } \\
\text { Therapy }\end{array}$ & $\begin{array}{l}256 \mathrm{sp} \\
\mathrm{Neg} \\
11 \cdot 4 \\
0 \cdot 36 \\
0 \cdot 22 \\
\text { Active } \\
5 \mathrm{mg} \mathrm{pr}\end{array}$ & $\begin{array}{l}256 \mathrm{sp} \\
\mathrm{Neg} \\
39 \cdot 4 \\
0.72 \\
2.58 \\
\text { renal SLE } \\
\text { nisolone }\end{array}$ & $\begin{array}{l}- \\
\overline{96} \\
0.47 \\
0.08 \\
\text { Active } \\
\text { Nil }\end{array}$ & $\begin{array}{l}256 \mathrm{H} \\
\mathrm{Neg} \\
99 \\
0.43 \\
0.08 \\
\text { al SLE }\end{array}$ & $\begin{array}{l}64 \mathrm{H} \\
\mathrm{Neg} \\
12 \\
1 \cdot 38 \\
0 \cdot 22 \\
\text { Inacti } \\
10 \mathrm{mg}\end{array}$ & $\begin{array}{l}256 \mathrm{H} \\
\mathrm{Neg} \\
47 \\
2 \cdot 43 \\
0 \cdot 18 \\
\text { onrenal SLE } \\
\text { ednisolone }\end{array}$ & $\begin{array}{l}\text { Neg } \\
\text { Neg } \\
15 \\
0.98 \\
0.24 \\
\text { Inactiv } \\
7.5 \mathrm{~m}\end{array}$ & $\begin{array}{l}64 \mathrm{H} \\
16 \\
32 \\
1 \cdot 50 \\
0.66 \\
\text { nrenal SLE } \\
\text { ednisolone }\end{array}$ & $\begin{array}{l}16 \mathrm{H} \\
\mathrm{Neg} \\
9 \\
0 \cdot 78 \\
0 \cdot 24 \\
\text { Inactiv } \\
\text { Nil }\end{array}$ & $\begin{array}{l}1000 \mathrm{H} \\
\text { Neg } \\
14 \\
1 \cdot 35 \\
0 \cdot 3 \\
\text { scoid LE }\end{array}$ \\
\hline
\end{tabular}

$\mathrm{ANF}=$ antinuclear factor; DNAB =DNA-binding; $\mathrm{Sp}=$ speckled; $\mathrm{H}=$ homogeneous. 
Table 2 Results of placental immunofluorescence (IgG/C3/fibrinogen)

\begin{tabular}{|c|c|c|c|c|c|}
\hline Placenta & $\begin{array}{l}\text { Trophoblast basement } \\
\text { membrane }\end{array}$ & Fibrinoid & Stroma & $B V$ & $\begin{array}{l}\text { Nuclear } \\
\text { fluorescence }\end{array}$ \\
\hline $\begin{array}{l}A \\
B \\
C \\
D \\
E\end{array}$ & $\begin{array}{l}+(L) \\
+(L / G) \\
+(L) \\
+(L) \\
+(L)\end{array}$ & $\begin{array}{l}+(\mathbf{H} / \mathbf{G}) \\
+(\mathbf{H} / \mathbf{G}) \\
+(\mathbf{H} / \mathbf{G}) \\
+(\mathbf{H} / \mathbf{G}) \\
+(\mathbf{H} / \mathbf{G})\end{array}$ & $\begin{array}{l}+(G) \\
+(G) \\
+(G) \\
- \\
\pm(G)\end{array}$ & $\begin{array}{l}+(G) \\
+(G) \\
+(G) \\
\pm(G) \\
+(G)\end{array}$ & $\begin{array}{l}+ \\
- \\
- \\
-\end{array}$ \\
\hline
\end{tabular}

$\mathbf{L}=$ linear; $\mathbf{G}=$ granular.

'tramline' fluorescence was seen on the trophoblast basement membranes of all placentae (Fig. 1). All these patterns have been demonstrated previously in normal placentae (McCormick et al., 1971; Faulk et al., 1974). However, on the trophoblast basement membranes of patient $B$ granular deposition of IgG and C3 was also seen (Figs. 2 and 3). In addition, in tissue from patient $A$ a speckled pattern of nuclear fluorescence in some cytotrophoblast cells was also seen with the antiserum to IgG.

In sections of placenta from patient $B$ there was appreciable reduction in granular IgG-specific fluorescence on the trophoblast basement membrane and in the stroma after incubation with deoxyribonuclease. In control sections washed with PBS, no such diminution of staining was observed.

\section{ELUTION STUDIES}

When the acidic eluates were examined by immunoelectrophoresis, IgG and fibrinogen were detected in all eluates, C3 in three and IgM in one (Table 3). The eluate obtained from placenta $B$ by incubation with deoxyribonuclease also contained IgG. The

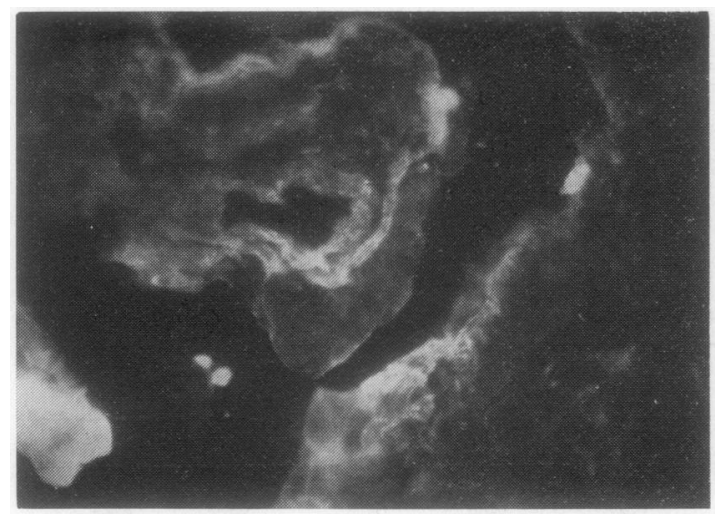

Fig. 1 Section of placenta $C$ stained with FITClabelled anti-IgG showing linear, 'tramline' fluorescence along the trophoblast basement membrane of a placental villus. The fluorescent area at bottom left is a mass of fibrinoid material. $\times 260$.

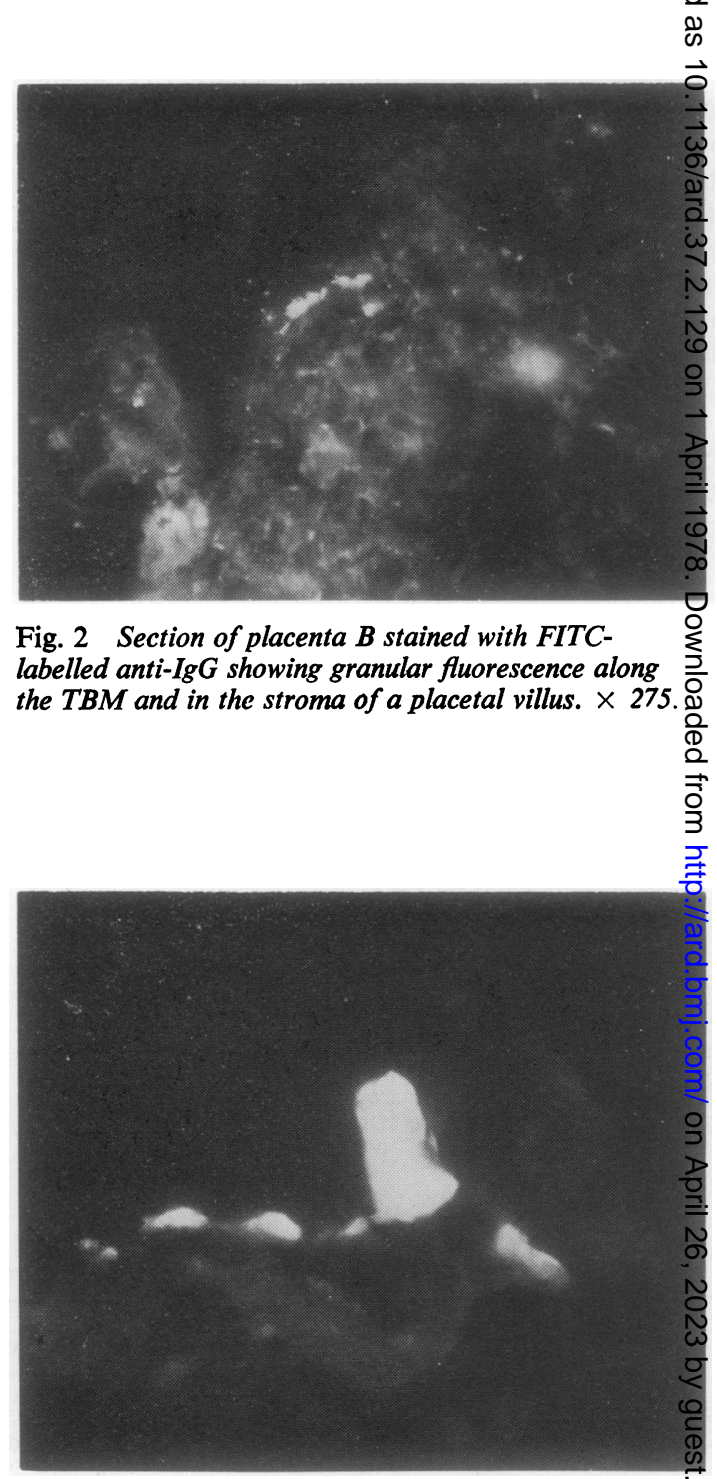

Fig. 3 Section of placenta B stained with FITClabelled anti-C3 showing 'lumpy' deposits of $C 3$ on the $\bar{P}$ trophoblast basement membrane of a placental villus. The larger fluorescent mass is an area of fibrinoid deposition. $\times 470$. 
Table 3 Immunological studies on placental eluates

\begin{tabular}{|c|c|c|c|c|c|c|c|c|}
\hline Placenta & $I g G$ & $I g M$ & $\operatorname{IgA}$ & C3 & Fibrinogen & $A N F$ & $R F$ & $D N A B$ \\
\hline $\boldsymbol{A}$ & + & - & - & + & + & $+\mathbf{s p}$ & - & 0 \\
\hline$B$ & + & - & - & + & + & $+++\mathbf{H}$ & - & $57 \%$ \\
\hline$C$ & + & - & - & - & + & - & - & $0^{10}$ \\
\hline$D$ & + & + & - & + & + & - & - & 0 \\
\hline$E$ & + & - & - & - & + & - & - & 0 \\
\hline
\end{tabular}

eluate from placenta A contained antinuclear antibody which produced a speckled pattern of nuclear fluorescence at low dilution (1/16), while the acidic eluate from placenta $B$ produced homogeneous nuclear fluorescence at the dilution of $1 / 128$ (Fig. 4). The eluate obtained from placenta $B$ by incubation with deoxyribonuclease produced peripheral or shaggy nuclear fluorescence at a dilution of $1 / 8$ (Fig. 5). Only the acidic eluate from placenta $B$ contained DNA-binding antibody (DNA binding capacity $57 \%$ ). The eluates from five placentae from healthy mothers were all negative for antinuclear factor and DNA-binding activity.

\section{Discussion}

One of the 5 patients investigated had active renal lupus at the time of delivery with presumed circulating immune complexes as suggested by very low complement $\mathrm{C} 3$ and $\mathrm{C} 4$ levels and profuse proteinuria. There was a high level of anti-DNA antibodies in the maternal serum and DNA antibodies were also found in the fetal serum, presumably reflecting passive transfer of anti-DNA antibodies across the placental barrier from the maternal to the

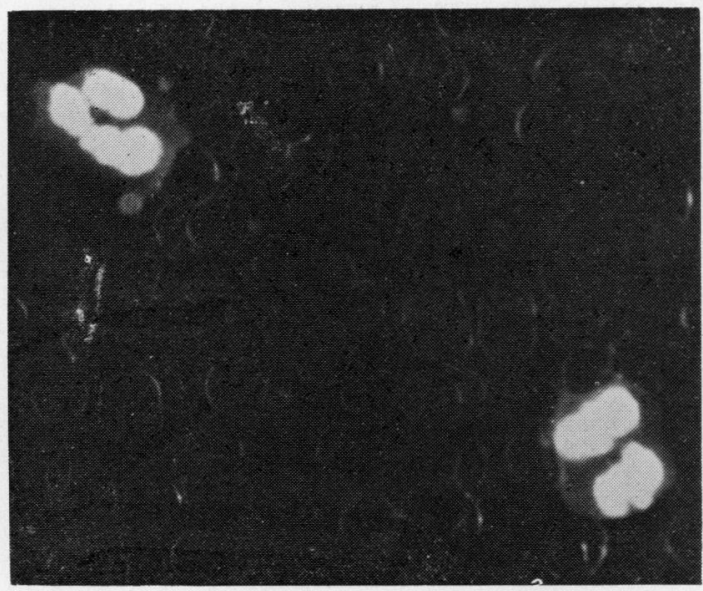

Fig. 4 Normul blood incubated with acidic eluate from placenta B and stained with FITC-labelled anti-IgG. Homogeneous nuclear fluorescence is shown. $\times 300$. fetal circulation. This contention is supported by the fall in DNA binding capacity in the baby's serum to $52 \%$ in 2 weeks and to $9 \% 8$ weeks after birth and is in keeping with previous reports of the passive transfer of the LE cell factor across the placental barrier in mothers with SLE (Bridge and Foley, 1954; Cox, 1965). The subsequent good health of the baby during its first 8 weeks of life emphasises the fact that DNA antibodies per se are not necessarily pathogenic. The lower levels of DNA antibodies in patients A, C, and D did not produce measurable levels of DNA antibodies in the corresponding fetal cord sera. Antinuclear antibodies were detected in the cord sera from patients $\mathrm{A}, \mathrm{C}$, and $\mathrm{E}$ and again presumably reflect passive transfer of antibodies across the placental barrier. All the babies were well.

Placental immunofluorescence showed, in addition to the findings which have been described in normal placentae by McCormick et al. (1971), that there was weak, speckled nuclear fluorescence in scattered cytotrophoblast cells in the placenta from patient $\mathrm{A}$.

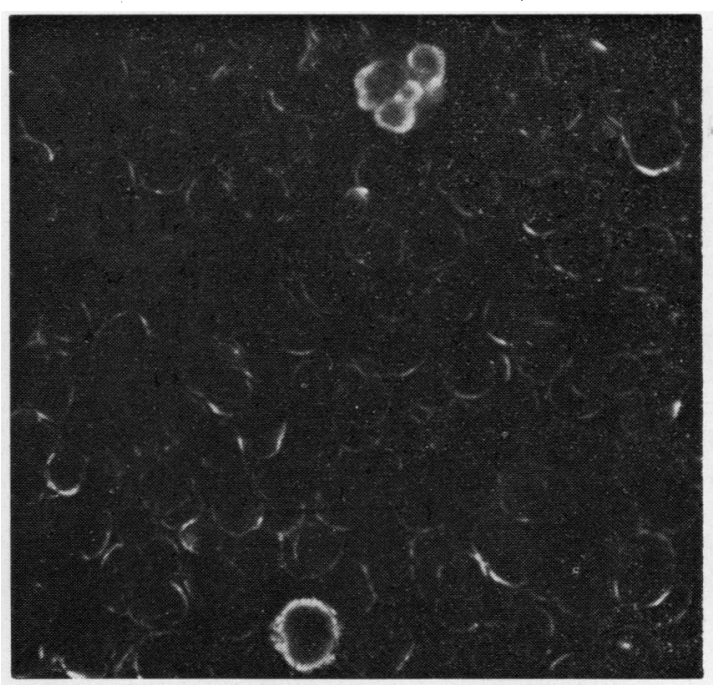

Fig. 5 Normal blood film incubated with the deoxyribonuclease eluate from placenta $B$ and stained with FITC-labelled anti-IgG. Peripheral or 'shaggy' nuclear fluorescence is shown. $\times 400$. 
This corresponded to the antinuclear factor in the patient's serum which similarly produced a speckled pattern on indirect immunofluorescence. Antibody to extractable nuclear antigen was also detected in the patient's serum. The acidic eluate from the same patient's placenta again produced a speckled immunofluorescence pattern and although $\mathrm{Gm}$ typing was not carried out it is very likely that the antinuclear factor was of maternal origin. The significance of this speckled nuclear fluorescence seen in the placenta from this patient is uncertain but it may have been due to post-partum penetration of cells by antinuclear factor from maternal blood rather than fixation of antinuclear factor in vivo.

More strikingly, in patient B there was deposition of IgG and C3 on the trophoblast basement membrane in a granular pattern similar to that shown on the glomerular basement membrane in patients with SLE (e.g. Koffler et al., 1967). The acidic eluate from this patient's placenta contained antinuclear factor at high titre $(1 / 128)$ and DNA binding antibody $(57 \%)$. IgG with antinuclear factor activity was also released from this placenta by incubation with deoxyribonuclease. Similarly, IgG was removed from sections of this placenta by incubation with deoxyribonuclease. These findings suggest deposition of DNA/anti-DNA complexes in the placenta by a mechanism analogous to that which occurs in the kidney in SLE. This would be in keeping with the presence of active renal disease in this patient. Immune complex deposition on the trophoblast basement membrane may be one factor contributing towards the increased fetal mortality reported in patients with active SLE (Mund et al., 1963).

We are grateful to Professor I. Donald and the consultant staff of the Queen Mother's Hospital for allowing us to study their patients, and to Mrs C. Bell for measurement of antinuclear factor and rheumatoid factor. D.M.G. is in receipt of an A. H. Robins Co. Clinical Research Fellowship. The Rheumatic Diseases Unit, Northern General Hospital, Edinburgh is in receipt of a grant from the Arthritis and Rheumatism Council.

\section{References}

Agnello, V., Koffler, D., and Kunkel, H. G. (1973). Immunee complex systems in the nephritis of systemic lupus erythe: matosus. Kidney International, 3, 90-99.

Alexander, W. R. M., and Duthie, J. J. R. (1958). Reaction of lupus erythematosus serum with nuclei of circulating and non-circulating cells. British Medical Journal, 2, 1565-156 Beck, J. S. (1961). Variations in the morphological patter of 'autoimmune' nuclear fluorescence. Lancet, 1, 1203-1206.

Bridge, R. G., and Foley, F. E. (1954). Placental transmissiof of the lupus erythematosus factor. American Journal of Medical Sciences, 227, 1-8.

Clark, H. F., and Shepard, C. C. (1963). A dialysis technique for preparing fluorescent antibody. Virology, 20, 642-644

Cox, J. B. (1965). Disseminated lupus erythematosus pregnancy. Obsterics and Gynecology, 26, 511-514.

Faulk, W. P., Jeannet, M., Creighton, W. D., and Carbonară A. (1974). Immunological studies of the human placenta Characterization of immunoglobulins on trophoblastia basement membranes. Journal of Clinical Investigation, 5i43 1011-1019.

Fraga, A., Mintz, G., Orozco, J., and Orozco, J. H. (1974 Sterility and fertility rates, fetal wastage and maternal morbidity in systemic lupus erythematosus. Journal $\overrightarrow{\partial f}$ Rheumatology, 13, 293-298.

Grishman, E., and Churg, J. (1971). Connective tissue 강 systemic lupus erythematosus. Demonstration of dissemit. nated vascular and extra-articular 'wire loop' deposits. Archives of Pathology, 91, 156-166.

Hughes, G. R. V. (1971). Significance of anti-DNA antio bodies in systemic lupus erythematosus. Lancet, 2, 861-863

Koffler, D., Schur, P. H. and Kunkel, H. G. (1967). Immunological studies concerning the nephritis of systemic lup erythematosus. Journal of Experimental Medicine, $12 \%$, 607-624.

McCormick, J. N., Faulk, W. P., Fox, H., and Fudenber. H. H. (1971). Immunohistological and elution studies of the human placenta. Journal of Experimental Medicine, 133, 1-18.

McDevitt, H. O., Peters, J. H., Pollard, L. W., Harter, J. G. and Coons, A. H. (1963). Purification and analysis of fluorescein-labelled antisera by column chromatography. Journal of Immunology, 90, 634-638.

Mund, A., Simson, L., and Rothfield, N. F. (1963). Effect pregnancy on course of systemic lupus erythematosus. Journal of the American Medical Association, 183, 917-924.

Paronetto, F., and Koffler, D. (1965). Immunofluorescent localization of immunoglobulins, complement and fibgnogen in human diseases. Journal of Clinical Investigation, 44, 1657-1664.

Schur, P. H., and Sandson, J. (1968). Immunological factors and clinical activity in systemic lupus erythematosus. New England Journal of Medicine, 278, 533-538.

Tan, E. M., and Kunkel, H. G. (1966). An immunofluorescent study of the skin lesions in systemic lupus erythematosul Arthritis and Rheumatism, 9, 37-46.

Tan, E. M., Schur, P. H., Carr, R. I., and Kunkel, H. N (1966). Deoxyribonucleic acid (DNA) and antibodies to DNA in the serum of patients with systemic lupus erythematosus Journal of Clinical Investigation, 45, 1732-1740. 